\title{
Tecnologia de Celulose e Papel no INPA
}

O interesse do INPA pela tecrologia papeleira data de 1956, quando surgiu, em Publicações Avulsas, $n .^{\circ} 2$, do INPA, o trabalho de Lechthaler "Sobre o problema do aproveitamento racional das madeiras da Amazônia".

A formação de pessoal altamente especializado e o equipamento dos laboratórios exigiu alguns anos. Em 1969, surgia um novo trabalho, de Lobato e Corrêa, sobre a Celulose de Ecolinusa ucuquirana, Eschwilera odora e Coryothophora, (Ciência e Cultura 21 (2) : 434-488, 1969). A partir de então foi intensificado o estudo das propriedades papeleiras de madeiras da Amazônia e já em 1970, Corrêa, Lobato e Ribeiro publicaram o "Estudo Papeleiro de Madeiras da Amazônia", trabalho laureado pela Associação Brasileira de Celulose e Papel. Em 1972, era publicado em Acta Amazonica 2(3) o "Estudo Papeleiro do Marupá", de autoria de Corrêa e Ribeiro.

Concluído o estudo de várias dezenas de espécies nativas, passou-se a estudar o rendimento de misturas de madeiras na proporção encontrada na floresta heterogênea previamente inventariada (estrada Manaus-Itacoatiara).

A partir de então, os trabalhos passaram a receber a orientação técnica do Sr. G. Petroff, do Centre Technique Foréstier Tropical que, dentro do programa de Cooperação Técnica, visitou o INPA e elaborou o Relatório da Missão Petroff, documento básico para a pesquisa sobre Celulose e Papel na Amazônia.

Com a mudança do instituto para a nova sede, o setor de Celulose e Papel foi dotado de maior e melhor espaço físico, podendo receber novo e moderno equipamento capaz de multiplicar a sua produtividade.

No decurso dos trabalhos realizados foram identificadas dezenas de espécies como boa fonte de celulose. As pesquisas foram todas realizadas com o apoio, valioso, dos setores de Botânica, Anatomia de Madeiras, Silvicultura e Ciências do Ambiente, o que permitiu segurança na identificação de espécie, estudo completo e sistemático das fibras, estudo de distribuição geográfica de cada espécie e ambiente em que vegeta, além da observação do seu comportamento em plantios isolados ou em enriquecimento.

Destacam-se como espécies particularmente valiosas o "marupá", o "morototó", o "paricá" e a Trema micrantha.

A Trema micrantha é largamente difundida na região neotrópica, e conhecida desde 1759, quando foi descrita por Linneu como Rhamus micranthus. O gênero recebeu outras denominações: Cettis, em 1817; Sponia, em 1834 e somente em 1853 Blume introduziu a denominação Trema micrantha. Apesar de conhecida há longo tempo, somente em 1973 foram identificadas as suas propriedades papeleiras conforme trabalho de Ribeiro publicado nesta edição de Acta Amazonica. 
A luz dos trabalhos já realizados, parece provado que existem na flora Amazônica essências superiores ao eucalipto como fonte de celulose. Superiores quanto ao rendimento, superiores quanto à qualidade do produto, superiores quanto à rapidez do crescimento. O processamento parece que seria também mais econômico no caso de certas essências.

Também está demonstrada a exequibilidade do aproveitamento da floresta heterogênea, embora seja necessário descartar um certo número de essências para garantir a melhor qualidade do produto.

No presente estágio dos estudos, duas questões avultam em importância: qual a floresta artificial menos desvantajosa como substituto da floresta nativa explorada e onde seria economicamente viável uma usina de celulose.

A medida que a usina utilizar a floresta nativa, crescerá a preocupação com a futura fonte de celulose. Observaçōes de W. A. Rodrigues, ainda não publicadas, revelam o valor da regeneração natural. Mas um empreendimento econômico exigirá uma reposição mais rápida da fonte de matéria-prima e a floresta artificial será a solução inevitável. Já conhecemos diversas espécies que se prestariam para a formação de floresta artificial de alto rendimento. Todavia, a ecologia amazônica sugere a conveniência de ser evitadas as florestas homogêneas. Devemos então procurar associar as essências papeleiras nativas num plantio misto. O problema envolve estudos sobre a compatibilidade interespécies e sobre o espaçamento ótimo. Além da compatibilidade fito-social, deverá ser estudada a compatibilidade tecnológica: qual o comportamento da mistura dentro do processo tecnológico de produção? Este é um dos desafios com que se defronta no momento os setores de silvicultura, botânica e celulose e papel do INPA.

A outra questão crítica é a determinação do local onde seria viavel a usina cie celulose. Pouco adiantaria estudar as misturas provenientes de uma floresta hetorogênea, se ao final se constatasse a inviabilidade da instalação de uma usina naquele local.

No momento, busca o INPA assessoria econômica de alto nivel capaz de reconhecer os locais onde seria viável uma usina de celulose, consideradas as disponibilidades de água, energia elétrica, mão-de-obra e transporte a custo compatível com o valor do produto. Naqueles locais será feito o inventário florestal e será realizado o estudo papeleiro da floresta heterogênea existente.

A pesquisa sobre celulose e papel na Amazônia é assim uma attividade complexa, requerendo atividade multidisciplinar integrada, exigindo um complexo de laboratórios e estações experimentais como o que existe no INPA, caracterizando-o como órgão capaz de aceitar o desafio.

\section{O EDITOR}

\section{Editor Responsável: P. Almeida Machado INPA, Manaus - AM}

